\title{
BIOLOGICAL EVALUATION OF BALADY BREAD AS AFFECTED BY REPLACING WHEAT FLOUR WITH DIFFERENT LEVELS OF DATE FIBER
}

\author{
A. M. Hamoda(1), A. A. El-Bedawey(2), A. H. Khali((2) and A. A. Bakry(1) \\ (1) Food Technology Research Institute, Agriculture Research Center, Giza, Egypt \\ (2) Food Science and Technology Dept., Faculty of Agriculture Menoufia University, Egypt
}

Received: Dec. 19, 2017

Accepted: Feb. 12, 2018

\begin{abstract}
The present study aims to investigate the effect of replacing wheat flour in balady bread with different levels of date fiber (DF) on the body weight gain, feed efficiency ratio, triglyceride, lipoprotein, blood glucose, liver functions and kidney functions of hypercholesterolemic rats. Body weight gain, feed efficiency ratio, triglyceride, total cholesterol, LDL, VLDL, blood glucose, liver functions and kidney functions were decreased by feeding rats with balady bread prepared with different levels of DF. All these parameters were decreased by increasing the level of DF in the bread. However, HDL values had an opposite trend. Feeding rats with bread diets prepared with $20 \%$ DF for 4 weeks returned body weight gain, blood glucose, AST, albumin and creatinine in hypercholesterolemic rats to the normal values in negative control rats. However, triglyceride, total cholesterol, LDL, VLDL, ALT, total protein and ureain hypercholesterolemic rats did not return to the normal values in negative control rats.
\end{abstract}

Key words: Balady bread, date fiber, cholesterol, triglycerides, rats.

\section{INTRODUCTION}

Hypercholesterolemia is a major risk factor for coronary artery diseases (Pereira et al., 2004 and Sridevi et al., 2004). Cholesterol became known as the building material for artherosclerotic plaques deposits in the arteries (kwiterovich et al., 1992). Elevated plasma cholesterol, especially the low density lipoprotein (LDL), is known as a major risk factor in coronary heart disease (Castelli et al., 1986). In recent years, dietary fiber has received increasing attention from researchers and industry due to the likely beneficial effects on the reduction of hypercholesterolemia, hypertension, coronary heart related diseases, diabetes incidence, obesity and gastrointestinal disorders (Pereira et al., 2004; Elia and Cummings, 2007; Mann, 2007 and Van Dam and Seidell, 2007).

The dietary guidelines for American published jointly by the U.S. Department of Agriculture and Health and Human Services recommend eating food that have adequate amount of fiber. The National Cancer Institute recommends 20 to $\mathbf{3 0}$ grams of fiber per day with an upper limit of $35 \mathrm{~g}$. To meet these requirements, fibers are added to different food products. Bread produced from wheat flour represents the main diet component for Egyptian consumers. Therefore, the development of enriched bread with higher fiber content is one of the efficient ways to increase the fiber intake. Many forms of dietary fibers have been used in bread making. Among these dietary fiber forms are wheat bran, rice bran, flaxseed, date seed fiber, corn cop flour and pineapple peel fiber (Bouaziz et al., 2010; Khorshid et al., 2011; Hamzah and Lian, 2012; Majzoobi et al., 2013; Ameh et al., 2013 and Ming-yin and Shiau, 2015).

The scientific community continues to search for new sources of dietary fiber as 
an alternative in fulfilling consumer demands for high fiber bread. Dates are good source of dietary fiber (Elleuch et al., 2008). Dietary fiber content of dates ranged from 4.4 to $11.4 \%$ depending on date variety and ripening stage (AIShahib and Marshall, 2002). A serving of dates (five to six fruit dates) can provide $14 \%$ of the recommended daily intake of the dietary fiber (Spiller, 1993). Date fiber (DF) is a by-product of date syrup (Debis) extraction. The current study was designed to incorporate date fiber with wheat flour at various levels to produce high fiber bread.

The aim of the study was to evaluation the effect of balady bread containing different levels $(5,10,15$ and $20 \%)$ of date fiber (DF) on the biological parameters in hypercholesterolemic rats.

\section{MATERIALS AND METHODS Materials}

Date fiber (DF) (Phoenix dactylifera L.), a by-product of date syrup (Debis) was obtained from El-Tahan factory, Elwhat, Egypt. The date fiber (DF) was dried in a vacuum oven at $70^{\circ} \mathrm{C}$ to constant weight as described by Kirk and Sawyer (1991). After drying, date fiber was ground and passed through a 0.6$\mathrm{mm}$ mesh sieve to obtain a fine date fiber powder and stored in sealable polyethylene bags in a desecrator.

Wheat flour of (Triticum aestivam) 82\% was obtained from Agriculture college, Cairo University, Egypt.

Male albino rats (Sprague Dawely strain) were obtained from animal housed in the Food Technology Research Institute, Agriculture Research Center, Giza, Egypt.

Casein, salts mix, vitamin mix, cholesterol powder, cholin chloride, cholic acid, D-methionine and cellulose were obtained from Modern Lab. for Chemicals and Lab. Equipments, Dokki, Cairo, Egypt. Starch was obtained from Egyptian Starch and Glucose Manufacturing Company Mostorod, Cairo, Egypt.

Chemical kits for determination of serum cholesterol, serum (HDL, LDL, VLDL) cholesterol, serum triglycerides, serum glucose, serum ALT, serum AST, serum total protein, serum albumin serum creatinine and serum urea were obtained from Alkan-Medical Division, Giza, Egypt.

\section{Methods \\ Preparation of balady bread containing date fiber \\ Date fibers were dried in a vacuum} oven at $70^{\circ} \mathrm{C}$ and ground to a powder form. Wheat flour $82 \%$ was partially substituted with various levels of date fiber $(5,10,15$ and 20\%). Balady bread was prepared according to the method described by Attia-Afaf (1986).

\section{Experimental animal and design}

Thirty six male albino rats $(100 \mathrm{~g} \pm 5)$ were fed on a basal diet (AIN, 1993) for 10 days as an adaptation period. The basal diet was consisted of casein (15\%), corn oil $(10 \%)$, cellulose $(5 \%)$, salt mixture (4\%), vitamins mixture (1\%) and starch (65\%). Salt mixture and vitamins mixture were prepared according to A.O.A.C. (1990). Rats $(n=36)$ were randomly divided into two main groups. The first group (negative control group, $n=6$ ) was fed on basal diet. The second group was the hypercholesterolemic rats $(n=30)$. This group was fed on diet containing cholesterol (1\%), cholic acid (0.2\%), cholin chloride $(0.18 \%)$ and cow and tail fat $(12 \%)$ for 6 weeks. After the end of the hypercholesterolemic period, the second group was divided into 5 subgroups (6 rats per subgroup). The first subgroup 
(positive control) was fed on standard diet. The other four subgroups were fed on standard diet containing $10 \%$ balady bread formulated with $5,10,15$ and $20 \%$ date fiber. All groups were fed on the experimental diet for 30 days.

\section{Induction of experimental hypercholesterolemia}

Rats feed hypercholesterolemic diet (1\% cholesterol) for 4 weeks, and then fasting blood serum obtained to insure cholesterol level for overnight.

\section{Blood sampling}

Blood samples were collected after 12 $\mathrm{hr}$ of fasting at the end of the experiment. Blood was collected into a dry clean centrifugal tube and left to clot in a water bath $\left(37^{\circ} \mathrm{C}\right)$ at room temperature for half an hour. The blood was centrifuged for 10 minutes at $3000 \mathrm{rpm}$ to separate the serum which was carefully aspirated and transferred into clear quit fit plastic tubes and kept frozen at $-20^{\circ} \mathrm{C}$ until analysis.

\section{Organs}

Liver, kidney, heart and spleen were removed, washed with saline solution, weighted and kept in formalin solution $(10 \%, v / v)$ according to the method described by Drury and Wallington (1980).

\section{Biological evaluation}

All rats were weighted at the beginning and at the end of the experiment to determine the body weight gain (BWG). The body weight gain, feed efficiency ratio (FER) and relative organs weight were determined according to Chapman et al. (1959).

\section{Biochemical analysis \\ Determination of serum lipids}

Triglycerides were determined according to Fassati and Prencipe (1982). Total cholesterol and HDL were determined according to the methods described by Allain (1974). LDL and VLDL were determined according to the method of Lee and Nieman (1996) and calculated using the following equations:

LDL $(\mathrm{mg} / \mathrm{dl})=$ Total cholesterol $-(\mathrm{HDL}+$ VLDL).

VLDL $(\mathrm{mg} / \mathrm{dl})=$ Triglycerides $\div 5$.

\section{Determination of glucose}

Glucose was determined by enzymatic test using chemical kits according to Trinder (1969).

\section{Determination of kidney functions \\ Uric acid and creatinine were} determined according to the method of While et al. (1970) and Henry (1974) respectively.

Determination of liver functions, total protein and albumin

Alanine aminotransferase (ALT) and aspartate aminotransferase (AST) were determined according to the method of Tietz (1976) and Henry (1974). Albumin and total protein were analyzed according to Doumas et al. (1971) and Tietz (1995) respectively.

\section{Statistical Analysis:}

Data were analyzed using a completely randomized design (SAS, 1985) when a significant main effect was detected, the means were separated with the student-Newman-Keuls test. Differences between treatments of $(p \leq 0.05)$ were considered significant.

\section{RESULTS AND DISCUSSION}

Effect on the body weight gain and feed efficiency ratio

Body weight gain and feed efficiency ratio of the rats fed basal diet and balady bread diets prepared with different levels of DF are shown in Table 1. The results showed that positive control rats had 
higher $(P \leq 0.05)$ body weight gain than negative control rats as well as rats fed balady bread diets prepared with DF. No significant $(P>0.05)$ difference in body weight gain was observed between negative control rats and rats fed bread diet prepared with $20 \%$ DF. Body weight gain was significantly $(P \leq 0.05)$ decreased by increasing the level of DF in the bread diets. Body weight gain of rats fed bread diet prepared with $20 \%$ DF was reduced by $47.6 \%$ as compared to positive control rats.

This indicated that feeding rats with bread diet prepared with $20 \%$ DF returned the body weight of the rats to the normal weight. These results are in good agreement with those reported by Esposito et al. (2003) who found that dietary fiber demonstrated the ability to regulate energy intake thus enhancing weight loss or maintenance of a healthier body weight. Similar results were also reported by Hanaa Hemeda and Hala Khattab (2010) who reported that body weight gain was decreased by feeding hypercholesterolemic rats with $10 \%$ roasted bottle gourd seed husks as a source of dietary fiber.

Data in Table 1 showed that positive control rats had higher $(P \leq 0.05)$ feed efficiency ratio than negative control rats. Feed efficiency ratio of rats fed balady bread diets prepared with DF up to $10 \%$ was significantly $(P \leq 0.05)$ higher than negative control rats. However, at higher concentrations of DF, the feed efficiency ratio of rats was significantly $(P \leq 0.05)$ lower than negative control rats. In general, the feed efficiency ratio was significantly $(P \leq 0.05)$ decreased by increasing the level of DF in the bread diets. These results are in agreement with those obtained by Hanaa Hemeda and Hala Khattab (2010) who indicated that bottle gourd seed husks reduced the feeding efficiency ratio of hypercholesterolemic rats. The role of DF in energy intake regulation and obesity development is related to its unique physical and chemical properties that aid in early signals of satiation and enhanced or prolonged signals of satiety (Malkki, 2004).

Table 1: Effect of partial replacement of wheat flour in balady bread with different levels of date fiber (DF) on body weight gain and feed efficiency ratio of rats

$\begin{array}{lll}\text { Treatments } & \text { Body weight gain }{ }^{1} & \text { Feed efficiency ratio }\end{array}$

(g)

\begin{tabular}{llc}
\hline Control negative & $22.87^{\mathrm{d}}$ & $1.60^{\mathrm{c}}$ \\
Control positive & $39.49^{\mathrm{a}}$ & $1.92^{\mathrm{a}}$ \\
DF-5\% & $35.68^{\mathrm{b}}$ & $1.86^{\mathrm{ab}}$ \\
DF-10\% & $33.83^{\mathrm{b}}$ & $1.80^{\mathrm{b}}$ \\
DF-15\% & $25.78^{\mathrm{c}}$ & $1.55^{\mathrm{cd}}$ \\
DF-20\% & $20.71^{\mathrm{d}}$ & $1.25^{\mathrm{e}}$ \\
LSD & 2.24 & 0.06 \\
\hline${ }^{1}$ Mean in the same column with different letters are significantly different $(\mathrm{P} \leq 0.05)$.
\end{tabular}




\section{Effect on the organ weight}

Organ weights of the rats fed basal diet and balady bread diets prepared with different levels of DF are shown in Table 2. The results showed that positive control rats had higher $(P \leq 0.05)$ organ weight than negative control rats and rats fed bread diets prepared with DF. Organ weight of rats fed bread diets prepared with DF was significantly $(P \leq 0.05)$ higher than negative control rats. In general, organ weight was significantly $(\mathrm{P} \leq 0.05)$ decreased by increasing the level of DF in the bread diets. Heart, liver, kidney and spleen weights of the rats fed bread diet prepared with $20 \%$ DF were reduced by $27.6,11.5,20.9$ and $28.8 \%$ respectively compared to positive control rats. As a result of increasing the body weight gain (Table, 2), organ weight was increased. Similar reduction in organs weights was reported by Hanaa Hemeda and Hala Khattab (2010) and Sayed-Ahmed (2014). These results differed from those obtained by Amira Abd ElGwad (2012) who observed that hypercholesterolemic did not affect the organ weight.

\section{Effect on the triglyceride and lipoproteins}

The effects of replacing wheat flour in balady bread with different levels of DF on triglyceride and lipoproteins in rats are presented in Table 3 . The results showed that positive control rats had higher $(\mathrm{P} \leq 0.05) \quad$ triglyceride, total cholesterol, LDL and VLDL values than negative control rats and rats fed bread diets prepared with DF. However, HDL values had an opposite trend. Amira Abd ElGwad (2012) found that supplementing rats with high level of dietary fiber improved HDL as compared with unsupplemented rats. Kasahara et al. (2001) evaluated the hypolipidemic effect of cabbage on human and showed that HDL-cholesterol level increased significantly by taking high level of dietary fiber for 2 weeks after the start of the diet.

Rats fed bread diets prepared with DF had $(P \leq 0.05)$ higher triglyceride, total cholesterol, LDL and VLDL than negative control rats. Triglyceride, total cholesterol, LDL and VLDL were significantly $(P \leq 0.05)$ decreased by increasing the level of DF in the bread diets. Suido et al. (2002) found that the broccoli and cabbage showed cholesterol lowering effects in hypercholesterolemic rats. Hussein (2012) and Amira Abd ElGwad (2012) reported that supplemented hypercholesterolemic rats with dried cabbage fiber reduced triglyceride, total cholesterol, LDL and VLDL compared to unsupplemented hypercholesterolemic rats.

Table 2: Effect of partial replacement of wheat flour in balady bread with different levels of date fiber (DF) on organ weight of rats

\begin{tabular}{lcccc}
\hline Treatments & \multicolumn{4}{c}{ Organs weight ${ }^{1}(\mathrm{~g})$} \\
\cline { 2 - 5 } & Heart & Liver & Kidney & Spleen \\
\hline Negative control & $0.560^{\mathrm{e}}$ & $6.81^{\mathrm{e}}$ & $1.70^{\mathrm{e}}$ & $0.500^{\mathrm{f}}$ \\
Positive control & $1.147^{\mathrm{a}}$ & $10.02^{\mathrm{a}}$ & $2.25^{\mathrm{a}}$ & $0.720^{\mathrm{a}}$ \\
DF-5\% & $0.953^{\mathrm{b}}$ & $9.52^{\mathrm{b}}$ & $1.94^{\mathrm{b}}$ & $0.613^{\mathrm{b}}$ \\
DF-10\% & $0.910^{\mathrm{bc}}$ & $9.23^{\mathrm{c}}$ & $1.85^{\mathrm{c}}$ & $0.570^{\mathrm{c}}$ \\
DF-15\% & $0.863^{\mathrm{cd}}$ & $9.11^{\mathrm{c}}$ & $1.83^{\mathrm{c}}$ & $0.540^{\mathrm{d}}$ \\
DF-20\% & $0.830^{\mathrm{d}}$ & $8.87^{\mathrm{d}}$ & $1.78^{\mathrm{d}}$ & $0.513^{\mathrm{e}}$ \\
LSD & 0.047 & 0.120 & 0.030 & 0.012 \\
\hline
\end{tabular}

${ }^{1}$ Mean in the same column with different letters are significantly different at $(p \leq 0.05)$. 
A. M. Hamoda, et al.,

Table 3: Effect of partial replacement of wheat flour in balady bread with different levels of date fiber (DF) on triglyceride and lipoproteins of rats

\begin{tabular}{lccccc}
\hline Treatments & Triglyceride $^{1}$ & $\begin{array}{c}\text { Total } \\
\text { cholesterol } \\
(\mathrm{mg} / \mathrm{dl})\end{array}$ & $\begin{array}{c}\text { LDL- } \\
\text { cholesterol }\end{array}$ & $\begin{array}{c}\text { VLDL- } \\
\text { cholesterol }\end{array}$ & $\begin{array}{c}\text { HDL- } \\
\text { cholesterol }\end{array}$ \\
\cline { 2 - 6 } & $\begin{array}{c}\text { Normal range } \\
(54.5-75.7)\end{array}$ & $\begin{array}{c}\text { Normal range } \\
(40-130)\end{array}$ & $\begin{array}{c}\text { Normal } \\
\text { range } \\
(29.5-39.2)\end{array}$ & $\begin{array}{c}\text { Normal } \\
\text { range } \\
(10.9-16.5)\end{array}$ & $\begin{array}{c}\text { Normal } \\
\text { range } \\
(45.2-69.3)\end{array}$ \\
\hline Negative control & $65.73^{\mathrm{f}}$ & $88.62^{\mathrm{f}}$ & $23.88^{\mathrm{f}}$ & $10.46^{\mathrm{f}}$ & $54.28^{\mathrm{c}}$ \\
Positive control & $152.60^{\mathrm{a}}$ & $221.38^{\mathrm{a}}$ & $155.85^{\mathrm{a}}$ & $23.91^{\mathrm{a}}$ & $41.62^{\mathrm{e}}$ \\
DF-5\% & $130.89^{\mathrm{b}}$ & $188.77^{\mathrm{b}}$ & $123.28^{\mathrm{b}}$ & $20.30^{\mathrm{b}}$ & $45.19^{\mathrm{d}}$ \\
DF-10\% & $126.71^{\mathrm{c}}$ & $163.84^{\mathrm{c}}$ & $92.82^{\mathrm{c}}$ & $16.69^{\mathrm{c}}$ & $54.33^{\mathrm{c}}$ \\
DF-15\% & $95.75^{\mathrm{d}}$ & $146.65^{\mathrm{d}}$ & $69.34^{\mathrm{d}}$ & $11.64^{\mathrm{d}}$ & $65.67^{\mathrm{b}}$ \\
DF-20\% & $87.85^{\mathrm{e}}$ & $136.35^{\mathrm{e}}$ & $54.38^{\mathrm{e}}$ & $10.94^{\mathrm{e}}$ & $71.03^{\mathrm{a}}$ \\
LSD & 0.52 & 0.69 & 1.54 & 0.13 & 0.53 \\
\hline
\end{tabular}

${ }^{1}$ Mean in the same column with different letters are significantly different at $(p \leq 0.05)$.

Although triglyceride, total cholesterol, LDL and VLDLwere reduced in the rats fed bread diets prepared with $D F$, but their values were still higher $(P \leq 0.05)$ than those of negative control rats. Similar results were reported by Hussein (2012) and Amira Abd ElGwad (2012). Triglyceride, total cholesterol, LDL and VLDL of rats fed bread diet prepared with $20 \%$ DF were reduced by $42.4 \%, \quad 38.4 \%, \quad 65.1 \%$ and $54.2 \%$ respectively compared to positive control rats. Sayed-Ahmed (2014) reported that total lipid, triglycerides, total cholesterol, LDL- C and VLDL- $C$ were decreased by increasing the pomegranate peel powder level in pan bread, while HDL- C was increased.

Positive control rats and rats fed bread diets prepared with DF had $(P \leq 0.05) \quad$ higher triglyceride, total cholesterol, LDL and VLDL than the negative control. Increasing fed of rats with bread diets prepared with DF for longer than 4 weeks might lower triglycerides, total cholesterol, LDL and VLDL to the negative control.

\section{Effect on the blood glucose level}

The blood glucose levels of rats fed basal diet and balady bread diets prepared with different levels of DF are shown in Table 4. positive control rats had higher $(\mathrm{P} \leq 0.05)$ blood glucose level (125.83 $\mathrm{mg} / \mathrm{dl})$ than negative control rats $(101.10 \mathrm{mg} / \mathrm{dl})$ and rats fed bread diets prepared with DF (94.28 - $117.79 \mathrm{mg} / \mathrm{dl})$. The blood glucose level of the rats fed bread diets prepared with DF was higher $(P \leq 0.05)$ than negative control rats with the exception of rats fed bread diet prepared with $20 \%$ DF. Rats fed bread diet prepared with 20\% DF had lower $(P \leq 0.05)$ blood glucose level than negative control rats. The blood glucose level was significantly $(P \leq 0.05)$ decreased by increasing the level of DF in the bread diets. At 20\% DF replacement level, blood glucose level was reduced $(P \leq 0.05)$ by $6.7 \%$ and $25.1 \%$ as compared to negative control rats and positive control rats respectively. These results agree well with those reported by Esposito et al. (2003) who reported that dietary fiber has been shown to lower the risk for type two diabetes, either through glycemic control or reduced energy intake. 
Table 4: Effect of partial replacement of wheat flour in balady bread with different levels of date fiber (DF) on blood glucose level of rats

\begin{tabular}{lc}
\hline & Glucose $^{1}(\mathrm{mg} / \mathrm{dl})$ \\
\cline { 2 - 2 } Treatments & $\begin{array}{c}\text { Normal range } \\
(50-135)\end{array}$ \\
\hline Negative control & $101.10^{\mathrm{e}}$ \\
Positive control & $125.83^{\mathrm{a}}$ \\
DF-5\% & $117.79^{\mathrm{b}}$ \\
DF-10\% & $112.75^{\mathrm{c}}$ \\
DF-15\% & $108.95^{\mathrm{d}}$ \\
DF-20\% & $94.28^{\mathrm{f}}$ \\
LSD & 1.75 \\
\hline${ }^{1}$ Mean in the same column with different letters are significantly different at $(\mathrm{p} \leq 0.05)$.
\end{tabular}

Effect on the liver functions, total protein and albumin

Several hepatic enzymes in serum were used for the biochemical markers to understand the early hepatic injury such as ALT and AST. Table 5 showed the effect of DF on the ALT, AST, total protein and albumin in rats. Negative control rats had lower $(P \leq 0.05)$ ALT and AST activities than positive control rats and rats fed bread diets prepared with DF with the exception of AST activity in rats fed bread diet prepared with $20 \%$ DF. Positive control rats had higher ( $P \leq 0.05)$ ALT and AST activities than rats fed bread diets prepared with DF with the exception of AST activity in rats fed bread diet prepared with 5\% DF. No significant $(P>0.05)$ difference in the AST activity between positive control rats and rats fed bread diet prepared with 5\% DF. ALT and AST activities were significantly $(P \leq 0.05)$ decreased by increasing the level of DF in the bread diets. At $20 \%$ DF replacement level, ALT and AST activities were reduced $(P \leq 0.05)$ by $18.6 \%$ and $24.2 \%$ as compared to positive control rats respectively. Sayed-Ahmed (2014) reported that liver function, of rats fed on high fat diet, decreased by increasing the level of pomegranate peel powder as a source of fiber in pan bread diet.

ALT activity (49.76 u/l) in positive control rats was higher $(P \leq 0.05)$ than the normal range $(17.5-30.2 \mathrm{u} / \mathrm{l})$. This is related to the hypercholesterolemic effect on ALT activity. Although ALT activity was reduced in the rats fed bread diet prepared with DF, but their values still higher $(P \leq 0.05)$ than the normal range. AST activity of all rats under this study was lower than the normal range (45.780.8u/l). Amira Abd ElGwad (2012) found that hypercholesterolemic rats supplemented with $15 \%$ dried red cabbage fiber reduced ALT and AST activities as compared to unsupplemented hypercholesterolemic rats. Total protein values of all rats under this study were higher than the value of the normal range $(5.6-7.6 \mathrm{~g} / \mathrm{dl})$. Positive control rats had higher ( $\mathrm{P} \leq 0.05)$ total protein than negative control rats and rats fed bread diets prepared with DF. 
A. M. Hamoda, et al.,

Table 5: Effect of partial replacement of wheat flour in balady with different levels of date fiber (DF) on liver functions of rats, total protein and albumin

\begin{tabular}{lcccc}
\hline Treatments & $\begin{array}{c}\text { ALT } \\
(\mathrm{u} / \mathrm{l})\end{array}$ & $\begin{array}{c}\text { AST } \\
(\mathrm{u} / \mathrm{l})\end{array}$ & $\begin{array}{c}\text { Total protein } \\
(\mathrm{g} / \mathrm{dl})\end{array}$ & $\begin{array}{c}\text { Albumin } \\
(\mathrm{g} / \mathrm{dl})\end{array}$ \\
\cline { 2 - 5 } & \multicolumn{5}{c}{ Normal range } \\
\cline { 2 - 5 } & $(17.5-30.2)$ & $(45.7-80.8)$ & $(5.6-7.6)$ & $(3.8-4.8)$ \\
\hline Negative control & $26.85^{\mathrm{f}}$ & $26^{\mathrm{d}}$ & $8.06^{\mathrm{f}}$ & $2.57^{\mathrm{e}}$ \\
Positive control & $49.76^{\mathrm{a}}$ & $33^{\mathrm{a}}$ & $8.75^{\mathrm{a}}$ & $3.13^{\mathrm{a}}$ \\
DF-5\% & $46.67^{\mathrm{b}}$ & $33^{\mathrm{a}}$ & $8.65^{\mathrm{b}}$ & $2.96^{\mathrm{b}}$ \\
DF-10\% & $45.28^{\mathrm{c}}$ & $30^{\mathrm{b}}$ & $8.56^{\mathrm{c}}$ & $2.80^{\mathrm{c}}$ \\
DF-15\% & $42.86^{\mathrm{d}}$ & $28^{\mathrm{c}}$ & $8.47^{\mathrm{d}}$ & $2.71^{\mathrm{d}}$ \\
DF-20\% & $40.48^{\mathrm{e}}$ & $25^{\mathrm{e}}$ & $8.23^{\mathrm{e}}$ & $2.25^{\mathrm{f}}$ \\
LSD & 0.49 & 0.67 & 0.03 & 0.03 \\
\hline
\end{tabular}

${ }^{1}$ Mean in the same column with different letters are significantly different at $(p \leq 0.05)$.

Total protein of the rats fed bread diets prepared with DF was higher $(P \leq 0.05)$ than negative control rats. Total protein was significantly $(P \leq 0.05)$ decreased by increasing the level of DF in the bread diets. At $20 \%$ DF replacement level, total protein was reduced $(P \leq 0.05)$ by $5.9 \%$ as compared to positive control rats.

Albumin values of all rats under this study were lower than the value of the normal range $(3.8-4.8 \mathrm{~g} / \mathrm{dl})$. Negative control rats had lower $(P \leq 0.05)$ albumin than positive control rats and rats fed bread diets prepared with DF with the exception of rats fed bread diet prepared with $20 \%$ DF. Albumin was significantly $(P \leq 0.05)$ decreased by increasing the level of DF in the bread diets. At $20 \%$ DF replacement level, albumin was reduced $(P \leq 0.05)$ by $12.5 \%$ and $28.1 \%$ as compared to negative control rats and positive control rats respectively.
Effect on the kidney functions

Urea is the end product of protein metabolism; an increasing in blood urea level usually indicates renal failure although it may also result from dehydration, gastrointestinal bleeding, congestive heart failure, high protein intake and insufficient renal blood supply. Elevated blood urea is referred to azotemia. Decreased in blood urea can result from liver disease (Lee and Nieman, 2003). Creatinine and urea of the rats fed basal diet (negative and positive control rats) and balady bread diets prepared with different levels of DF are shown in table 6. Positive control rats had higher $(P \leq 0.05)$ creatinine than negative control rats and rats fed bread diets prepared with DF. Rats fed bread diets prepared with $5 \%$ and $10 \%$ DF had higher $(p \leq 0.05)$ creatinine than negative control rats. However, rats fed bread diets prepared with $15 \%$ and $20 \%$ DF had lower $(p \leq 0.05)$ creatinine than negative control rats. 
Table 6: Effect of partial replacement of wheat flour in balady bread with different levels of date fiber (DF) on kidney functions of rats

\begin{tabular}{lcc}
\hline & \multicolumn{1}{c}{$\begin{array}{c}\text { Creatinine } \\
\text { mg/dl }\end{array}$} & $\begin{array}{c}\text { Urea } \\
\text { mg/dl }\end{array}$ \\
\cline { 2 - 3 } Treatments & \multicolumn{2}{c}{ Normal range } \\
\cline { 2 - 3 } & $(0.2-0.8)$ & $(15-25)$ \\
\hline Negative control & $0.55^{\mathrm{d}}$ & $23.43^{\mathrm{e}}$ \\
Positive control & $1.15^{\mathrm{a}}$ & $40.02^{\mathrm{a}}$ \\
DF-5\% & $0.79^{\mathrm{b}}$ & $32.34^{\mathrm{b}}$ \\
DF-10\% & $0.71^{\mathrm{c}}$ & $28.93^{\mathrm{bc}}$ \\
DF-15\% & $0.52^{\mathrm{e}}$ & $27.26^{\mathrm{cd}}$ \\
DF-20\% & $0.47^{\mathrm{f}}$ & $25.12^{\mathrm{de}}$ \\
LSD & 0.02 & 4.49
\end{tabular}

${ }^{1}$ Mean in the same column with different letters are significantly different at ( $\left.p \leq 0.05\right)$.

Creatinine was significantly $(P \leq 0.05)$ decreased by increasing the level of DF in the bread diets. At $5 \%$ and $20 \%$ DF replacement levels, creatinine was reduced $(P \leq 0.05)$ by $31.3 \%$ and $59.1 \%$ respectively as compared to positive control rats. Creatinine of the rats fed bread diets prepared with DF (0.47- 0.79 $\mathrm{mg} / \mathrm{dl}$ ) was within the normal and safe range (0.2-0.8 $\mathrm{mg} / \mathrm{dl})$. This indicated that feeding rats with bread diets prepared with DF returned the creatinine in rats to the normal range values. Amira Abd ElGwad (2012) found that hypercholesterolemic rats supplemented with $15 \%$ dried red cabbage fiber reduced creatinine values as compared to unsupplemented hypercholesterolemic rats.

Positive control rats had higher $(P \leq 0.05)$ urea than negative control rats and rats fed bread diets prepared with DF. Rats fed bread diets prepared with DF up to $15 \%$ had higher $(P \leq 0.05)$ urea than negative control rats. No significant $(P>0.05)$ difference in urea between negative control rats and rats fed bread diet prepared with $20 \%$ DF. Urea was significantly $(P \leq 0.05)$ decreased by increasing the level of DF in the bread diets. At $5 \%$ and $20 \%$ DF replacement levels, urea was reduced $(\mathrm{P} \leq 0.05)$ by $19.2 \%$ and $37.2 \%$ respectively as compared to positive control rats. Urea of rats fed bread diet prepared with 20\% DF was within the normal and safe range (15$25 \mathrm{mg} / \mathrm{dl})$. This indicated that feeding rats with bread diets prepared with $20 \%$ DF returned the urea in rats to the normal range values.

From the above results, it could be concluded that feeding rats with bread diets prepared by replacing wheat flour with different levels of DF reduced body weight gain, organ weight, triglyceride, total cholesterol, LDL and VLDL, and improvement the blood glucose, liver functions and kidney functions of hypercholesterolemic rats.

\section{Acknowledgements}

The authors gratefully acknowledge Dr. Esam El-Din H. Mansour for his scientific and technical assistance of this research. 


\section{REFFERENCES}

A.O.A.C. (1990). Official Methods of Analysis of Association of Official Agriculture Chemists, $11^{\text {th }}$ ed. Washington D.C.

AIN (1993). American Institute of Nutrition Purified Diet for Laboratory Rodent, final report. J. Essent. Oil Res. 8: 657664.

Allain, C. C. (1974). Cholesterol enzymatic colorimetric. Method, J. of Clin. Chem. 20:470.

Al-Shahib, W. and R. J. Marshall (2002). Dietary fiber content of dates from 13 varieties of date palm (Phoenix dactylifera L.) Internat. J. of Food Sci. and Technol. 37: 719-721.

Ameh, M. O., D. I. Gernah and B. O. Igbabul (2013). Physic-chemical and sensory evaluation of wheat bread supplemented with stabilized undefatted rice bran. Food and Nutrit. Sci. 4: 43-48.

Amira Abd ElGwad, E. (2012). The therapeutic effect of red cabbage on rats. M. Sc. Thesis, Nutration and Food Science Department, Faculty of Home Economics, Minufiya Univ., Shibin Elkom, Egypt.

Attia-Afaf, A. (1986). Physical and chemical studies on the staling of some Egyptian bread. Ph.D. thesis, Food Sci.Depart. CairoUniv. pp102-106.

Bouaziz, M. A., W. Ben Amara, A. Attia, C. Blecker and S. Besbes (2010). Effect of the addition of defatted date seeds on wheat dough performance and bread quality. J. Text. Studies 41:511531.

Castelli, W. P., R. J. Garrison, P. W. F. Wilson, R. D. Abbott, S. Kalousdian and W. B. Kannel (1986). Incidence of coronary heart disease and lipoprotein cholesterol levels. JAMA 256: 2835-2838.

Chapman, D. G., R. Castilla and J. A. Cambell (1959). Evaluation of protein in foods. LA. Method for determination of protein efficiency ratio.Can. J. Biochem. Physiol., 37:679-686.
Doumas, B.T., W.A. Watson and H.C. Biggsm (1971). Albumin standards and Management of serum albumin with bromocresol green. Chin. Chim. Acta. 31:87-96.

Drury, R. A. and E. A. Wallington (1980). Carton,s Histological Technique, $5^{\text {th }}$ Ed., Oxford Univ.

Elleuch, M., S. Besbes, O. Roiseux, C. Blecker and C. Deroanne (2008). Date flesh: chemical composition and characteristics of the dietary fiber. Food Chem. 111: 676-682.

Ellia, A. and J. H. Cummings (2007). Physiological aspects of energy metabolism and gastrointestinal effects of carbohydrates. Eur. J. Clin. Nutrit. 61: 40-74.

Esposito, K., F. Nappo, F. Giugliano, C. Di Palo, M. Ciotola, M. Barbieri, G. Paolisso and D. Giugliano (2003). Meal modulation of circulating interleukin 18 and adiponectin concentrations in healthy subjects and in patients with type 2 diabetes mellitus. American J. Clin. Nutrit. 78: 1135-1140.

Fassati, P. and L. Prencipe (1982). Triglyceride enzymatic colorimatic method. J. Clin. Chem. 28:2077.

Hamzah, Y. and W. F. Lian (2012). Physiochemical properties and acceptance of high fiber bread incorporated with corn cob flour. As. J. Food Ag.-Ind. 5: 547-553.

Hanaa M. H. and Hala A. H. K. (2010). The impact of bottle gourd seeds husks on rheological properties of pan bread and lipid profiles in hypercholesterolemic rats. World Appl. Sci. J. 9: 764-778.

Henry, R. J. (1974). Clinical Chemist: Principles and Techniques. $2^{\text {nd }}$, Edition, Hagerstoun (MD), Harcer, ROW, p.882.

Hussein, E. A. (2012). Potential Therapeutic Effects of dried Cabbage and Eggplant on the Hypercholesteromic Rats. Conference of Specific Education, Mansoura University, Mansoura, Egypt. 
Kasahara, T., O. Chonan, R. Takahas and F. Ishikawa (2001). Antioxidant and antiproliferative activities of common vegetables. J. of Agric. and Food Chem. 50: 6910-6916.

Khorshid, A. M., Nadia H. A. Assem, Nadia M. Abd El-Moteleb and Jermine S. Fahim (2011). Utilization of flaxseeds in improving bread quality. Eygypt J. Agric. Res. 89: 241-250.

Kirk, R. S. and R. Sawyer (1991). Pearson's Composition and Analysis of Foods $9^{\text {th }}$ edn. Pp. 28-31. London: Longman Scientific and Technical.

Kwiterovich, P. O., J. Coresh, H. H. Smith, P. S. Bachoric, C. A. Derby and T. A. Pearson (1992). Comparison of the plasma level of a poprotein B and A1 and other risk factors in men and women with premature coronary artery disease. Am. J. Cardiol. 69: 1015-1021.

Lee, R. and D. Nieman (1996). Nutrition Assessment, $2^{\text {nd }}$ Ed. Mosby, Missouri, USA pp. 591-594.

Lee, R. D. and D. C. Nieman (2003). Nutritional Assessment. McGraw Hill, New York.

Malkki, Y. (2004). Trends in dietary fiber research and development. Acta Alimentaria 33: 39-62.

Majzoobi, M., A. Farahnaky, Z. Nematolahi, M. Hashemi and T. J. Ardakani (2013). Effect of different levels and particle of wheat bran on the quality of flat bread. J. Agric. Sci. Technol. 15: 115-123.

Mann, J. (2007). Dietary carbohydrate relationship to cardiovascular disease and disorders of carbohydrate metabolism. Eur. J. Clin. Nutrit. 61: 100-111.

Ming-Yin, W. U. and S. Y. Shiau (2015). Effect of the amount and particle size of pinapple peel fiber on dough rheology and steamed bread quality. J. of Food Process. and preserv. 39: 549-558.
Pereira, M. A., E. O'Reilly, K. Augustsson, G. E. Fraser and U. Goldbourt (2004). Dietary fiber and risk of coronary heart disease: apooled analysis of cohort studies. Arch. Internat. Med. 164:370-376.

SAS, (1985). SAS User's Guide statistics, Cony, Nc: SAS. Instit.

Sayed-Ahmed, E. F. (2014). Evaluation of pomegranate peel fortified pan bread on body weightloss. Internat. J. of Nutrit. and Food Sci. 3: 411-420.

Spiller, G. A. (1993). Handbook of dietary fiber in human nutrition (pp 588) $2^{\text {nd }}$ Ed. Boca Raton, Florida: CRC.

Sridevi, D., J. Ishwarlal and S. VegaLopez (2004). Plant sterol fortified orange juice effectively lower cholesterol levels in mildly hypercholesterolemic healthy individuals. Arteriosclerosis, Thrombosis and Vascular Biol. 24:2528.

Suido, H., T. Tanaka, T. Tabei, A. Takeuchi, M. Okita, T. Kishimoto, S. Kasayama and K. Higashino (2002). A Mixed Green Vegetable and Fruit Beverage Decreased the Serum Level of Low-Density Lipoprotein Cholesterol in Hypercholesterolemic Patients. J. Agric. Food Chem. 50: 3346-3350.

Tietz, N. W. (1996). Fundamental of clinical chemistry, Philadelphia, (2) W. B. pp. 53-56.

Tietz, N. W. (1995). Clinical guide to laboratory test. W8 Saunders Co, Philadelphia pp. 518-522.

Trinder, P. (1969). Glucose enzymatic colorimetric method. J. Clin. Biochem. 6:24.

Van Dam, R. M. and J. C. Seidell (2007). carbohydrate intake and obesity. Eur. J. Clin. Nutrit. 61: 75-99.

While, B. A., M. M. Erickson and S. A. Steven (1970). Chemistry for Medical Theologies Ts. $3^{\text {Rd }}$ Ed., C.V. Mosby company Saint Louis, USA, P. 662. 
A. M. Hamoda, et al.,

\section{التقييم البيولوجي للخبز البلاي المصنوع باستبدال دقيق القمح بمستويات مختلفة

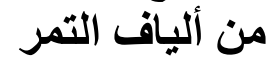

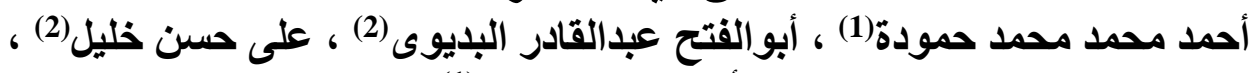

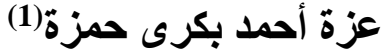

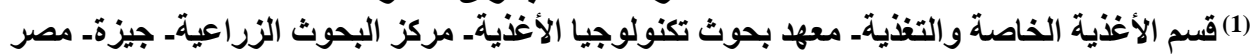

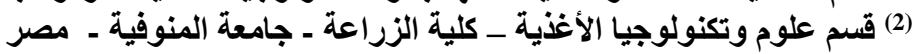

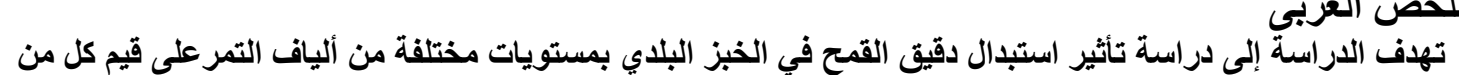

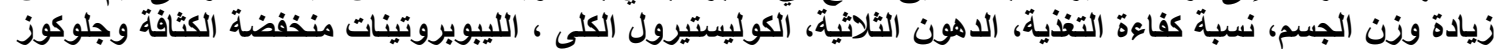

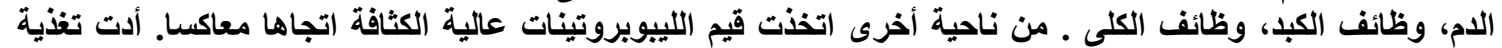

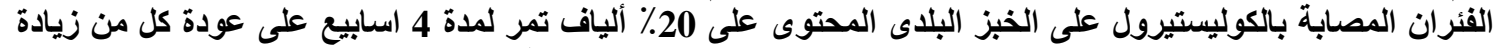

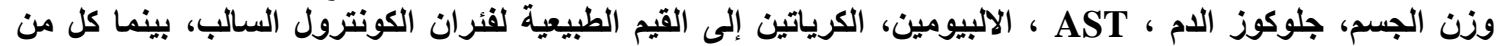

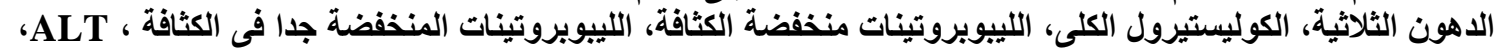
البروتين الكلى واليوريا فى الفئران المصابة بالكوليستيرول لم تعود إلى القيم الطبيعية لفئران الكونترول السيالب.

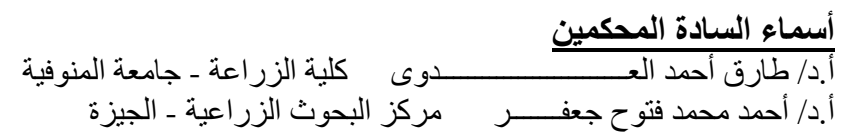

